\title{
THE FIRST WEEKS OF THE CORONAVIRUS CRISIS: WHO GOT HIT, WHEN AND WHY? EVIDENCE FROM NORWAY
}

\author{
Annette Alstadsæter \\ Bernt Bratsberg \\ Gaute Eielsen \\ Wojciech Kopczuk \\ Simen Markussen \\ Oddbjorn Raaum \\ Knut Røed \\ Working Paper 27131 \\ http://www.nber.org/papers/w27131 \\ NATIONAL BUREAU OF ECONOMIC RESEARCH \\ 1050 Massachusetts Avenue \\ Cambridge, MA 02138 \\ May 2020
}

This article is part of the report from the research project "Temporary and permanent layoffs under Covid-19". Thanks to the Norwegian Directorate of Labour and Welfare and Statistics Norway for supplying the registry data, to Trond Vigtel for assistance with the data, and to Maria Hoen for assistance with the linking of data from the $\mathrm{O} *$ NET database to Norwegian occupation codes. The views expressed herein are those of the authors and do not necessarily reflect the views of the National Bureau of Economic Research.

NBER working papers are circulated for discussion and comment purposes. They have not been peer-reviewed or been subject to the review by the NBER Board of Directors that accompanies official NBER publications.

(C) 2020 by Annette Alstadsæter, Bernt Bratsberg, Gaute Eielsen, Wojciech Kopczuk, Simen Markussen, Oddbjorn Raaum, and Knut Røed. All rights reserved. Short sections of text, not to exceed two paragraphs, may be quoted without explicit permission provided that full credit, including $(\odot$ notice, is given to the source. 
The First Weeks of the Coronavirus Crisis: Who Got Hit, When and Why? Evidence from

Norway

Annette Alstadsæter, Bernt Bratsberg, Gaute Eielsen, Wojciech Kopczuk, Simen Markussen, Oddbjorn Raaum, and Knut Røed

NBER Working Paper No. 27131

May 2020

JEL No. E24,J11,J4,J6

\section{ABSTRACT}

Using real-time register data we document the magnitude, dynamics and socio-economic characteristics of the crisis-induced temporary and permanent layoffs in Norway. We find evidence that the effects of social distancing measures quickly spread to industries that were not directly affected by policy. Close to $90 \%$ of layoffs are temporary, although this classification may change as the crisis progresses. Still, there is suggestive evidence of immediate stress on a subset of firms that manifests itself in permanent rather than temporary layoffs. We find that the shock had a strong socio-economic gradient, hit a financially vulnerable population, and parents with younger children, and was driven by layoffs in smaller, less productive, and financially weaker firms. Consequently though, the rise in unemployment likely overstates the loss of output associated with the layoffs by about a third.

Annette Alstadsæter

School of Economics and Business

Norwegian University of Life Sciences

P.O. Box 5003, NO-1432 Ås

Norway

annette.alstadsater@nmbu.no

Bernt Bratsberg

Ragnar Frisch Centre for Economic Research

Gaustadalléen 21, 0349 Oslo

Norway

bernt.bratsberg@frisch.uio.no

Gaute Eielsen

Department of Research and Analysis

Norwegian Directorate of Labor and Welfare

Norway

gaute.eielsen@nav.no

Wojciech Kopczuk

Columbia University

420 West 118th Street,

Rm. 1022 IAB MC 3323

New York, NY 10027

and NBER

wk2110@ columbia.edu
Simen Markussen

Ragnar Frisch Centre for Economic Research

Gaustadalléen 21, 0349 Oslo

Norway

simen.markussen@frisch.uio.no

Oddbjorn Raaum

Ragnar Frisch Centre for Economic Research

Gaustadalleen 21, 0349 Oslo

Norway

oddbjorn.raaum@frisch.uio.no

Knut Røed

Ragnar Frisch Centre for Economic Research

Gaustadalléen 21, 0349 Oslo

Norway

knut.roed@frisch.uio.no 
The coronavirus crisis hit fast all around the world. Its unprecedented nature and the response to it through social distancing led to massive reduction in economic activity. In Norway, where our data comes from, the measures were announced on March $12^{\text {th }}$ and during the following few weeks 360,000 people (approximately 12\% of the labor force) signed up for unemployment benefits, as Figure 1 demonstrates.

Figure 1: Unemployment benefits applications in Norway 3/1-4/19/2020
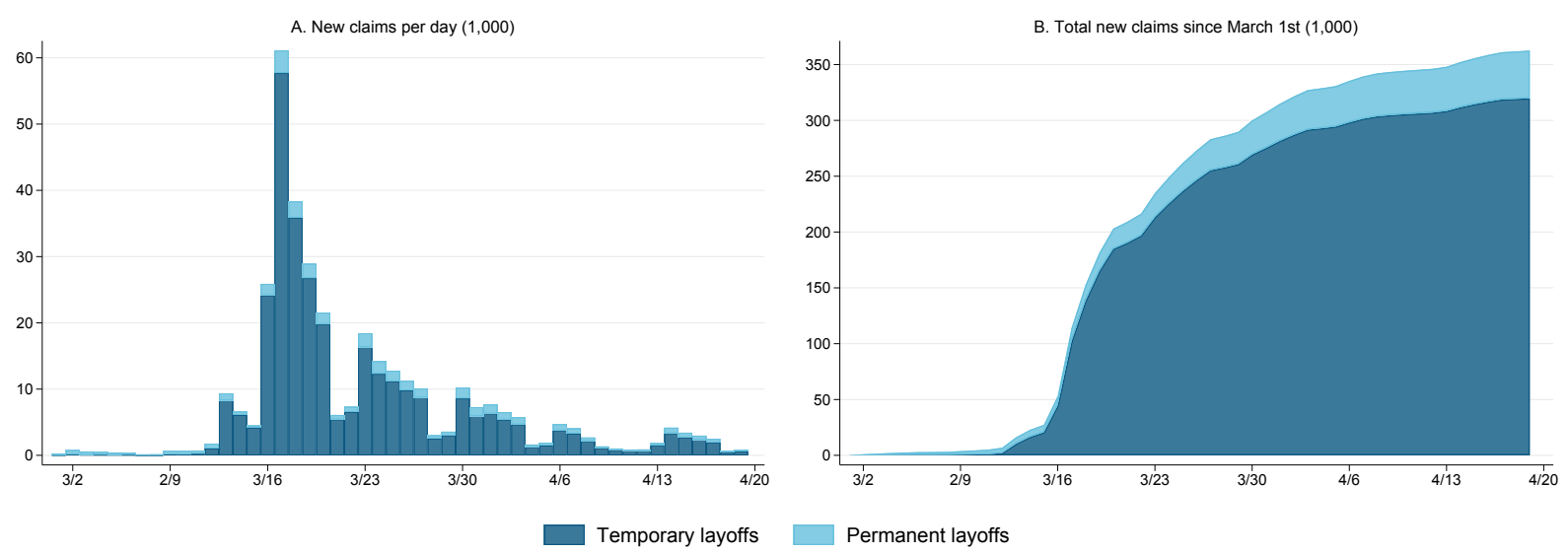

Note: Temporary and permanent layoffs refer to persons who have applied for unemployment benefits under the temporary or regular schemes of the UI program. Regular claims may include, in addition to dismissals, persons who have completed a fixed term employment contract. For each applicant we classify the person as temporarily or permanently laid off based on the latest filed application.

In the Norwegian context, workers filing for unemployment benefits may be laid off temporarily or permanently. Approximately 90 percent of the layoffs during the period covered here are temporary. That means that most of those applying for benefits retain employment relationships. There is, of course, a risk that temporary layoffs may turn into permanent layoffs later on. Berg et al. (2015), for example, shows that during the recession of 1993-95, about $15 \%$ of temporary layoffs did not return to the previous job. Previous studies also show that those exposed to unemployment during a temporary economic crisis have higher risk to be out of work in the longer term; see e.g. Yagan (2019).

On March 16, the Norwegian parliament agreed to change the rules for layoffs with immediate effect. Laid off workers will be paid full wages (up to an income limit of approximately NOK 600,000 - about USD 56,000) for the first 20 days. Afterwards, the benefits will be equal to $80 \%$ of income under NOK 300,000 and $62.4 \%$ for income between NOK 300,000 and 600,000. There is no compensation for lost income above NOK 600,000. Additionally, employers' responsibility for the first period of full pay was reduced from 15 to 2 days.

These changes in layoff regulations have been followed by additional crisis responses aimed at preventing bankruptcies, maintaining activity in municipalities and increased support for temporary training of laid off and unemployed.

We use almost real-time unemployment claims information linked to administrative registry data on past characteristics of individuals and firms to characterize which individuals and businesses were 
most affected, how the effect unfolded over the first few weeks, and the role that policy played in the process.

In this article, we take a closer look at who was most affected by the crisis during the first few weeks, both by loss of work through temporary or permanent layoff, and by being exposed to infection risk through work with socially critical functions. The article delves into a research literature that has studied heterogeneous effects of economic crises; see, for example, Hoynes et al. (2012), who find that the financial crisis in the United States has particularly affected minority groups, youth, and those with low education. Studies from Germany, Britain and Norway have also shown that immigrants are particularly vulnerable to economic fluctuations (Dustmann et al, 2010; Bratsberg et al, 2010; 2018). However, the crisis we are facing now is unique, both in terms of how quickly it has occurred, how many are affected, and not least in its underlying origins. It is thus far from obvious that studies of previous economic fluctuations provide a good basis for assessing the distributional effects of the crisis we are currently experiencing.

This paper also contributes to emerging literature on the impact of the crisis on the labor market and it does so with real-time administrative data rather than relying on survey-based or partial industry-based information (see for example Adams-Prassl et al, 2020, Bartik et al 2020, and Coibion, Gorodnichenko and Weber, 2020).

We have six main findings. First, layoffs started in sectors of the economy directly affected by the policy measures but then quickly spilled over to the rest of the economy so that after 4 weeks $2 / 3$ of layoffs are accounted for by businesses that were not directly targeted. Second, close to $90 \%$ of layoffs are temporary rather than permanent and while this classification may change as the crisis progresses, that is one glimmer of hope in the data. Third, while permanent layoffs are a minority, they still correspond to a 1.5 percentage point increase in unemployment — an unprecedented monthly change. Fourth, the layoffs have a strong socio-economic gradient and hit financially vulnerable populations. Fifth, there are hints of the important role of childcare - within firms, layoffs appear to be skewed toward workers with younger children, in particular toward women. Finally, layoffs are more common in less productive and financially weaker firms so that the employment loss may be overstating total output loss (although, the potential unobserved offsetting consideration is the possibility of underemployment of those that remained on the job).

\section{The data}

The primary database for this article is all individual unemployment benefit applications in Norway during the period from March $1^{\text {st }}$ to April $19^{\text {th }} 2020$, with information on whether the applications concerned ordinary unemployment or temporary layoffs. This means that in practice the analysis will include wage earners, entitled to unemployment benefits. As the annual income limit for entitlement to unemployment benefit was lowered from approximately NOK 125,000 to NOK 75,000 in connection with the current crisis, some applicants are very low income. We do not have information on financial problems among self-employed persons and persons whose main income comes from contract work. 
The population includes all persons residing in Norway as of January 1st 2019, and provides information about the employer (including industry), occupation, salary, previous income, education, age, sex, and country of birth, with links to spouse, children, and parents.

The employer has been identified on the basis of the so-called a-form, filed by all employers to the tax authority, in December 2019. The a-form includes information on occupation, current wages, and hours worked. Information on education is updated until October 2018, while information on previous income from all sources covers the period 1967-2017. The latter means that we can calculate total professional income so far in life quite precisely for the entire population.

As part of characterizing employees' occupations, we use information from O*NET (see www . onetonline.org), which, based on US data, provides a detailed description of the characteristics of various occupations. This information is then linked to the Norwegian standard for occupational classification (Hoen, 2016). In this article, one particular characteristic is of interest, namely the degree to which the job requires physical proximity to other people. Professions are described on a scale from 0 (do not work in the vicinity of others) to 100 (profession involves direct physical contact with others). This variable is standardized (in the US data), so that the average is equal to 0 and standard deviation is equal to 1 .

Since our information on occupation and hourly wage is based on information somewhat back in time, some of the employed will be "misplaced." This will happen for people who have switched jobs after December 2019. There are also some unemployment benefit applicants who cannot be matched to other data. This may be because they were not resident on January 1, 2019, or did not have a "normal" contract with an employer during 2019. Table 1 gives a more detailed description of the data. The analysis sample, described in column 1, consists of all wage recipients registered in 2019. Our data links enable us to capture a total of 330,492 of the 362,539 unemployment insurance applicants (91.2\%) in the period in question; see columns (2) and (3). Among the approx. 32,000 applicants that we do not match, one half are not residents in the country as of January 1, 2019 (column 5). The rest fall out of our analysis because we cannot connect them to an employer in 2019 (column 4).

\section{The Dynamics of the Crisis}

Even though the crisis hit widely, it did not hit at random. In this section we look more closely at which employees had to bear the negative consequences in the first few weeks. We will first and foremost focus on who lost the job, through temporary or permanent layoffs. But we will also look at who might bear the brunt by continuing to work in jobs with the risk of incurring infection. This latter group consists of people in "socially critical" professions with a great deal of physical proximity to other people, such as health personnel, nursing and care staff, and staff in grocery stores. $^{*}$

Figure 2 shows the composition of layoffs by different types of policies. The initial measures requiring social distancing were announced on Thursday, March 12, and the layoffs responded immediately, with a big spike in claims immediately after the weekend on Monday March 16 when 
Table 1: Summary statistics

\begin{tabular}{lc|cccc}
\hline \multirow{2}{*}{$\begin{array}{c}\text { Analysis } \\
\text { sample }\end{array}$} & \multicolumn{4}{c}{ UI benefit applicants 3/1 - 4/19/2020 } \\
& & Analysis sample & $\begin{array}{c}\text { Not included in } \\
\text { analysis sample }\end{array}$ \\
\cline { 3 - 6 } & & Temporary & Permanent & Resident & Non \\
& $(1)$ & $(2)$ & $(3)$ & $(4)$ & resident \\
& 40.7 & 38.6 & 35.6 & 39.8 & 37.5 \\
\hline Age & 48.5 & 45.7 & 46.6 & 44.9 & 22.8 \\
Female(\%) & 82.7 & 75.7 & 65.6 & 74.8 & 7.6 \\
Norwegian-born(\%) & 3.6 & 4.5 & 4.2 & 4.4 & 28.4 \\
Western Europe(\%) & 5.0 & 7.8 & 12.3 & 6.2 & 59.4 \\
New EU country(\%) & 8.7 & 12.0 & 17.9 & 14.5 & 4.6 \\
Other countries(\%) & 13.8 & 12.9 & 12.7 & 12.7 & 12.3 \\
Education (years) & 56.1 & 52.6 & 41.4 & & 16,042 \\
Income rank & 305.1 & 287.6 & 261.7 & & \\
Hourly wage(NOK) & 0.307 & 0.275 & 0.474 & & \\
Physical proximity index & & & & & \\
& & 295,848 & 34,644 & 16,005 & \\
Observations & $2,672,044$ & & & & \\
\hline
\end{tabular}

more generous rules (from both employee and employer's point of view) were announced.

We decompose this increase into four different categories. Group 1 includes individuals working in industries that were subject to the direct ban of activity (e.g., hairdressers, tattoo salons, bars). Group 2 includes workers of businesses that were subject to an implicit ban, typically from distancing restrictions (dentists, restaurants, etc), while Group 3 are workers of businesses that were subject to restrictions that prevented consumers from using those services, such as for hotels and airlines. Just $1 \%$ of workers were in Group 1, 5.7\% in Group 2, 4.4\% in Group 3, and 88.8\% of workers were not subject to any direct regulation. 
Figure 2: Layoffs by the type of restrictions
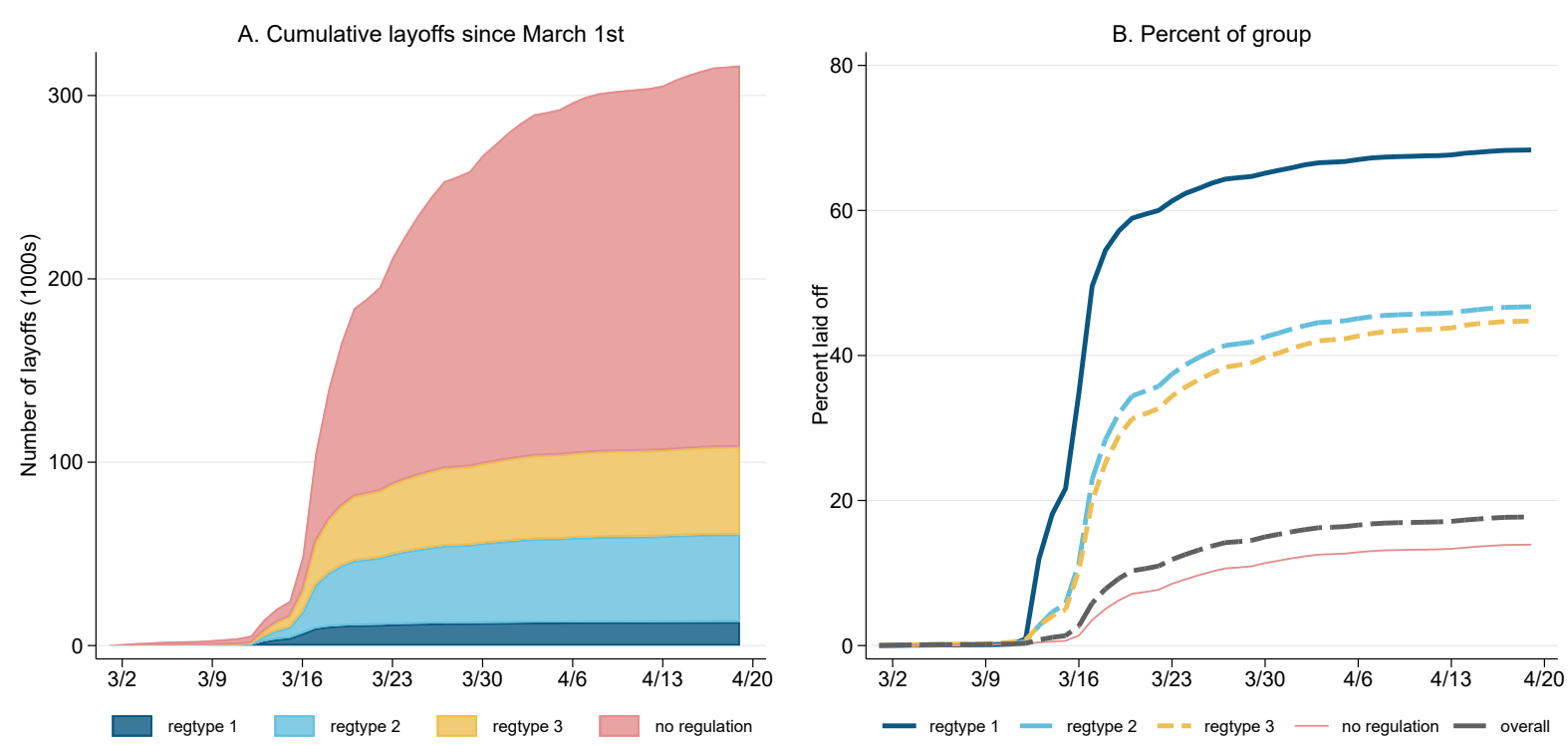

As a share of the group, layoffs in Group 1 were the largest, with close to $70 \%$ of the group laid off by the end of the period; the majority of them in the first few days. Groups 2 and 3 behaved similarly — a sizable immediate increase, a slower increase afterwards, reaching over $40 \%$ by the end of the period. These responses are not particularly surprising — they correspond to explicit or implicit restrictions on the activity. All three of these groups add up to a bit over $10 \%$ of employment but account for close to $1 / 3$ of layoffs.

The remaining $2 / 3$ of layoffs are accounted for by industries that did not face direct restrictions on their activity. Layoffs in that group were more spread out over time - they lagged layoffs in directly affected industries, but started building up a bit more gradually (although still with more than half of the layoffs over the whole period happening during the first week).

Figure 3 shows decomposition of layoffs into temporary and permanent ones. They do not follow the same time pattern — permanent layoffs build up more slowly over time. Of course, the size of the two groups is dramatically different. Permanent layoffs can be taken as a lower bound of employment ties that were severed permanently. In particular, the Norwegian system does not discourage temporary layoffs, so it is unlikely that permanent layoffs would revert to an employment relationship with the same employer at a later date. Viewed in that way, $1.5 \%$ of employment relationships in the whole economy ended permanently in the course of four weeks after March 12 - this would be a very large increase in unemployment at any time. In particular, a 1.5 percentage point increase is larger than any single month change in unemployment during the financial crisis. 
Figure 3: Temporary and permanent layoffs by the type of restrictions

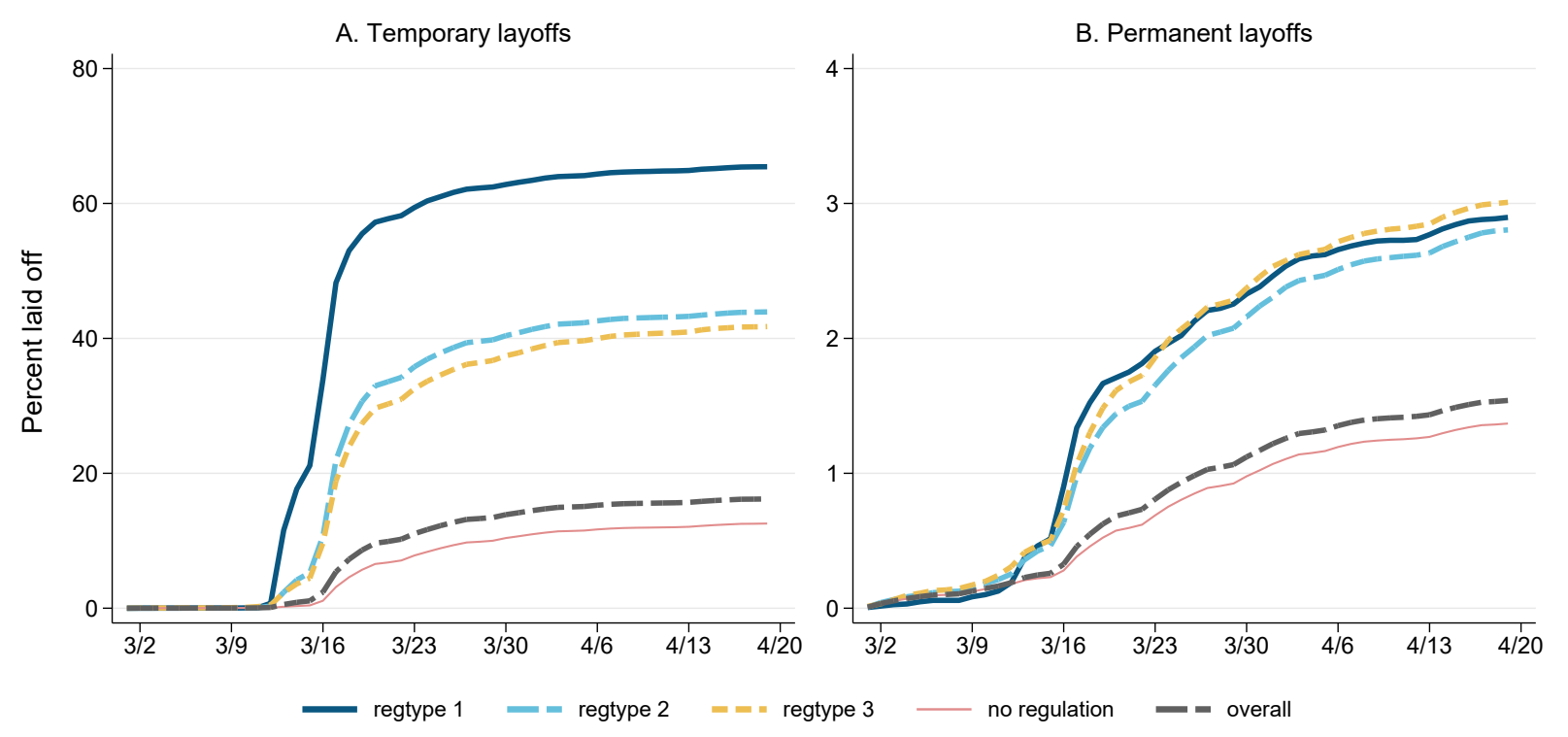

Speculating somewhat, permanent layoffs are likely to be revealing businesses in severe distress that are unlikely to survive the shock. One group of workers that may be permanently laid off are those on fixed term contracts that expire, but it is unlikely that they constitute the majority of the short-term effect. Otherwise, a permanent layoff in Norway requires the employer to pay severance, so that firms are expected to prefer temporary layoffs unless they are going bankrupt and this should be especially true at the time of a liquidity shock. 
Figure 4: Layoffs by firm size and the type of restrictions
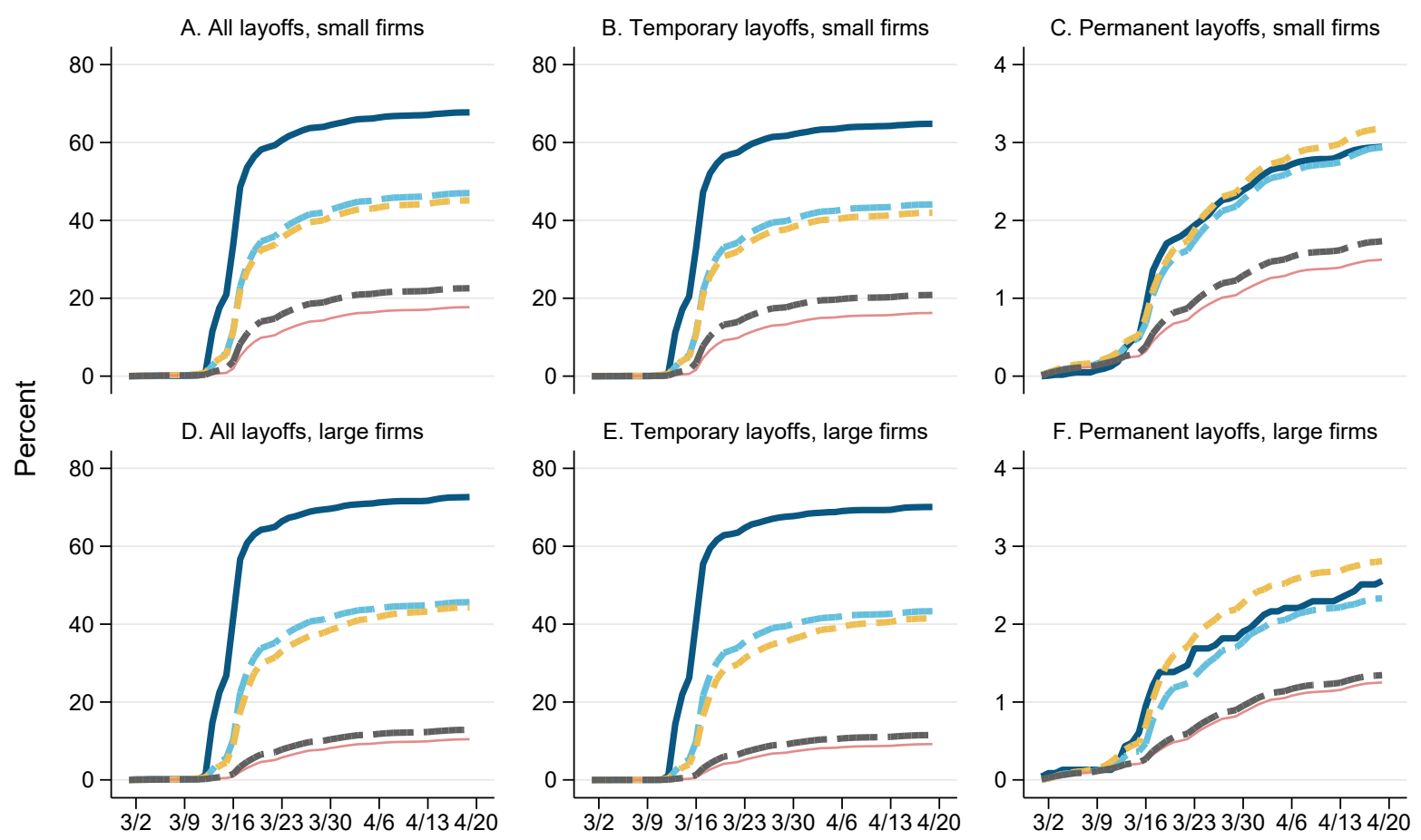

regtype $1 \quad-=$ regtype $2 \quad=-=$ regtype 3

no regulation - overall

Figure 4 shows that the behavior of small and large firms (below/above the median of 63 employees) in industries affected directly by restrictions is quite similar, with about the same level of layoffs and their composition into temporary and permanent ones. The main difference between larger and smaller firms comes from the "no regulation" group in which small firms reacted much more strongly.

\section{Production loss}

How large is the magnitude of the shock in terms of lost output? While direct information on this is not yet available, we can provide a guess based on employment loss and measures of worker productivity. Worker productivity is measured as value added (profits plus total wage bill) per man-year. Figure 5 shows the production loss based on the assumption that all workers are equally productive, such that the percentage loss in production corresponds to that of employment (yellow line). This is likely an overestimate of the production loss because industries that are affected are likely less productive. Reweighting employment loss by the average industry-level productivity implies output loss of about $15 \%$ by the end of the period. Using a firm-specific measure of productivity allows for accounting for selection within industries. As expected (because less productive firms are more likely to lay off employees), it attenuates the effect somewhat further. 
Figure 5: Production loss based on employment loss

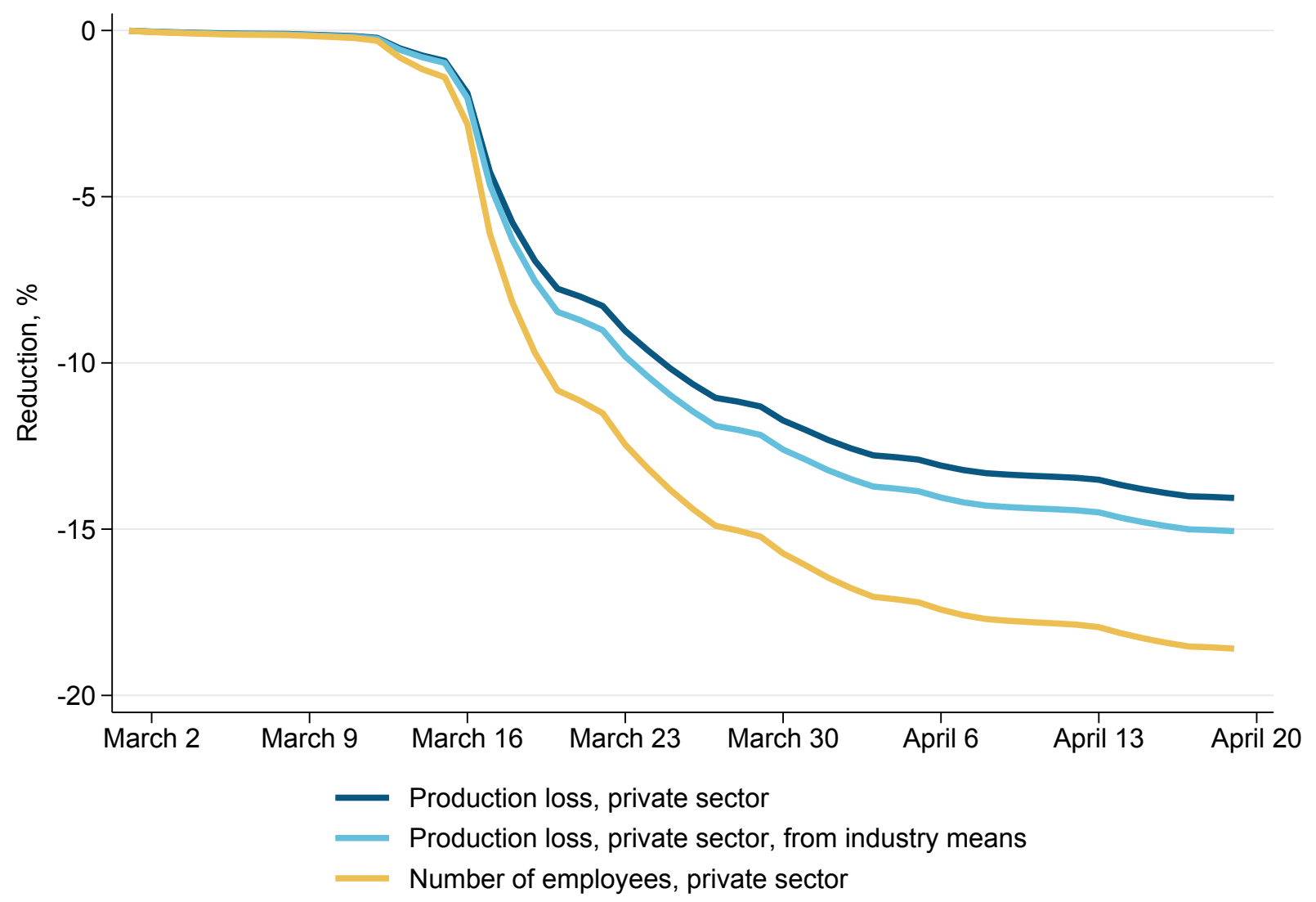

Is change in labor employed a good proxy for production loss? Of course, this is not a prediction of the loss of output in general. It does not account for the fact that even workers who remain employed may be less productive than they would have been otherwise. Going in the other direction, in Norway workers may be laid off for a fraction of their time and some temporarily laid off workers may have returned to work by April 19. At this point, our data does not allow for observing that.

\section{The "social gradient" of the crisis}

Figure 6 shows the incidence of socially critical risky work among all wage earners in Norway, based on their position in the age- and gender-specific distribution of total employment income throughout the professional career. Socially critical risky work is then defined as having a job of critical importance, in combination with a profession that requires physical closeness beyond the average in the whole economy. We divide the wage earners into ten equal groups by gender, according to their position in the age- and gender-specific income distribution.

The likelihood of holding an essential job with a high degree of physical proximity to others falls markedly with income levels, especially for men. There is also a remarkably large gender difference: Women are far more than men exposed to the combination of critical tasks and physical closeness 
to others. As many as 24.5 percent of the female workers have such jobs, which is about twice the corresponding proportion for men.

Figure 6: Share of employees in socially critical risk work, according to rank in age- and genderspecific distribution of lifetime income

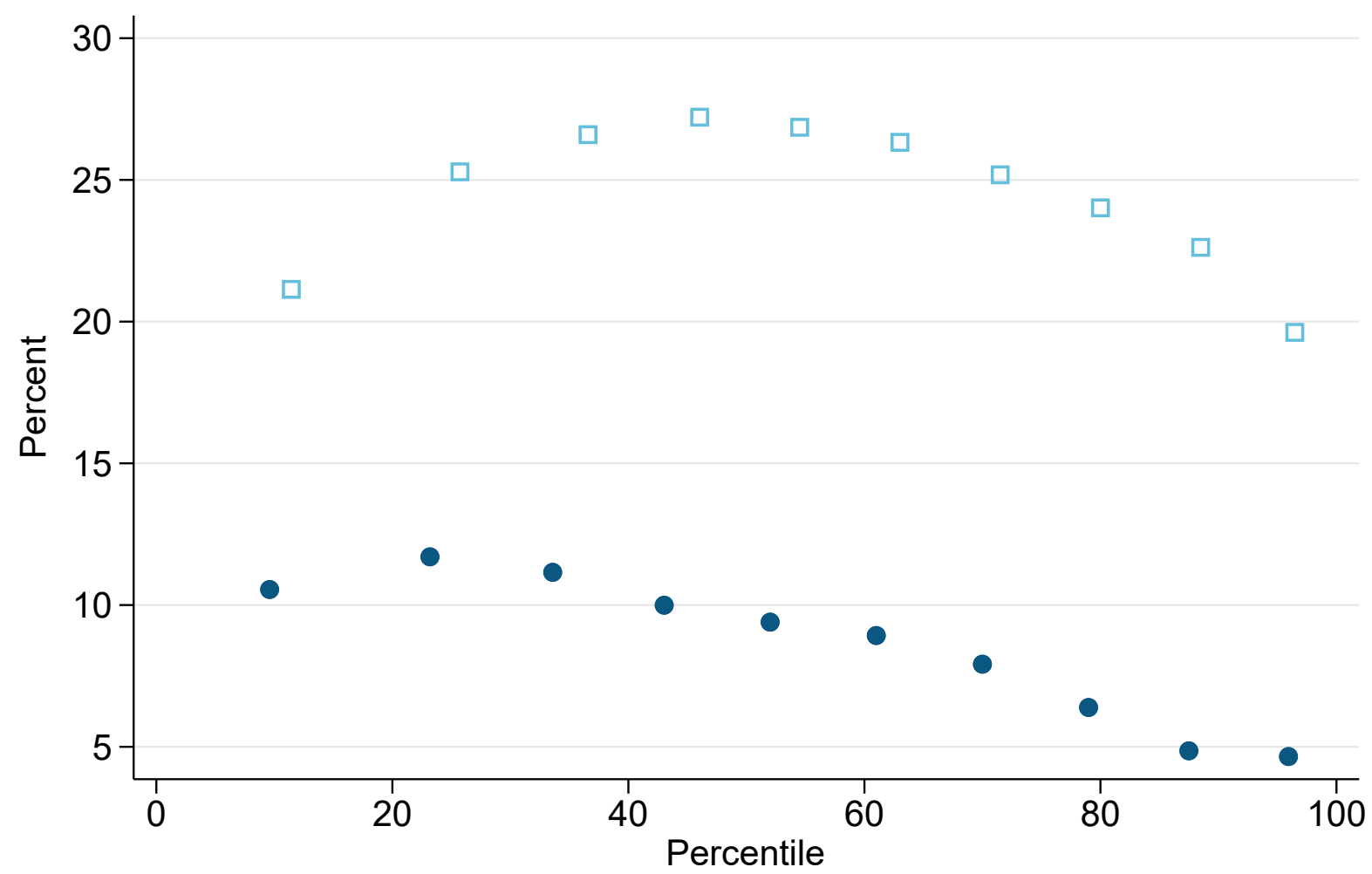

- Men $\square$ Women

Note: Critical function with a high degree of physical proximity is based on the coding of the ministries' list of personnel groups / positions covered by the exception to the main rule that children should be kept home from childcare and school to prevent the spread of infection, interacted with an indicator that the profession involves more physical closeness with others than the average. We have removed from this category 14,995 people classified as having an essential job, who were actually laid off or terminated in our data window. 63 percent of them come from one of the three professions salesperson in grocery / pharmacy / gas station, "other care worker," or bus and tram driver. The proportion with essential work with close physical proximity to others is 8.7 percent for men and 24.5 percent for women.

Figure 7 shows the extent of permanent and temporary layoffs for men and women by their position in the age and gender specific income distribution. We see that the likelihood of being hit by layoffs or termination falls sharply with income rankings. This social gradient is even more marked for permanent than for temporary layoffs. The probability of having permanently lost work during the first weeks of the coronavirus crisis is more than six times higher for people in the lower income deciles than at the top. The likelihood of being laid off is a little bit higher for men than for women. 
Figure 7: Percentage of temporarily and permanently laid-off workers according to rank in ageand gender-specific distribution of lifetime income
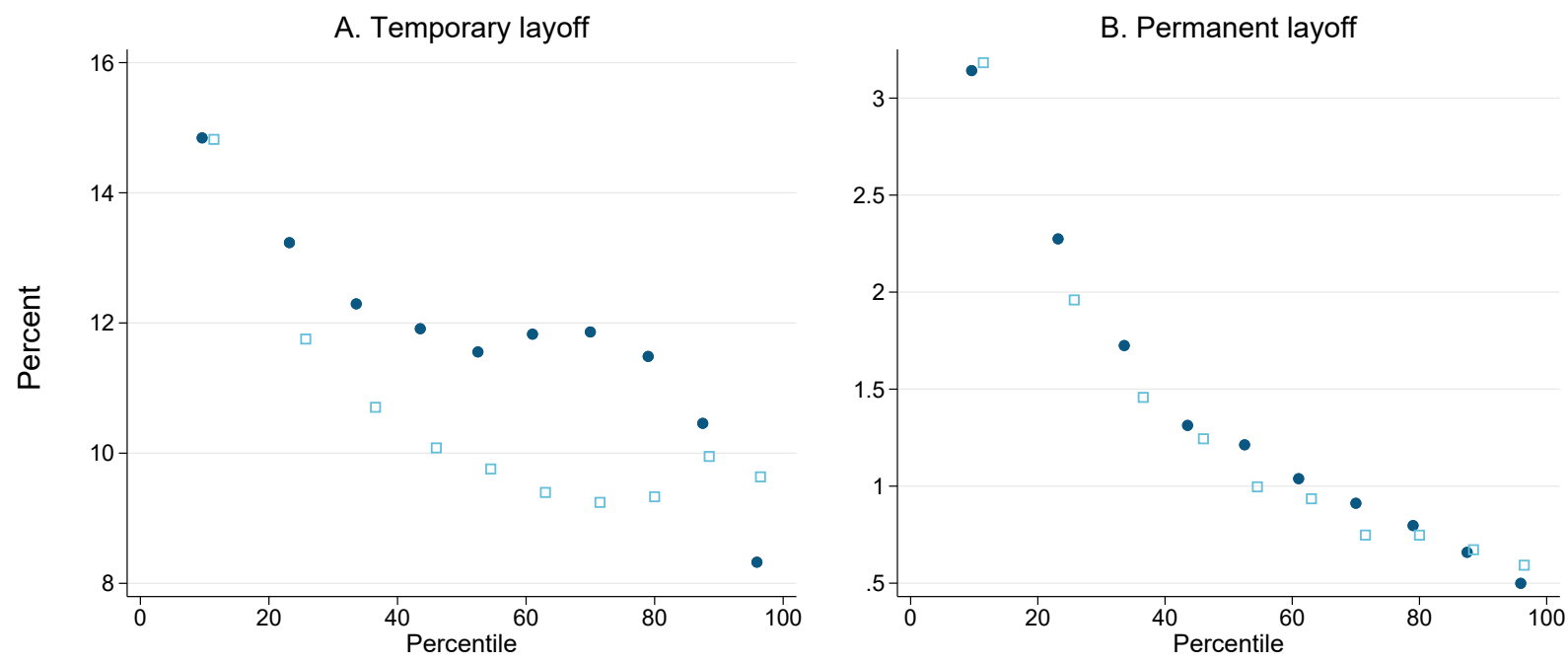

- Men $\square$ Women

Note: The percentage of temporary layoffs in our data is 11.7 percent for men and 10.4 percent for women. Corresponding shares of permanent layoff are 1.3 percent for men and 1.2 percent for women. The income rank is based on lifetime income. It is calculated by summing up all income earned in the period 1967-2017 for all residents in Norway. Subsequently, all employees are divided into ten equal groups by ranking in the income distribution. This is done within each birth cohort and separately for men and women.

We will now take a closer look at who, in the period from March $1^{\text {st }}$ to April $19^{\text {th }}$, lost the job on a temporary or permanent basis, and who applied for unemployment benefit. We will not separate between temporary and permanent unemployment benefits in what follows unless stated otherwise. The distinction between these two outcomes over the longer haul is not clear, as some of the temporary unemployed may end up being permanently dismissed

Figure 8 gives a broader idea of the socioeconomic composition of all the new claims during the first stage of the coronavirus crisis. We see that the social gradient is clear no matter how we capture socio-economic background. There is an overrepresentation among new unemployed people of low-income, low-education, and low hourly wages. 
Figure 8: Layoffs by socioeconomic status
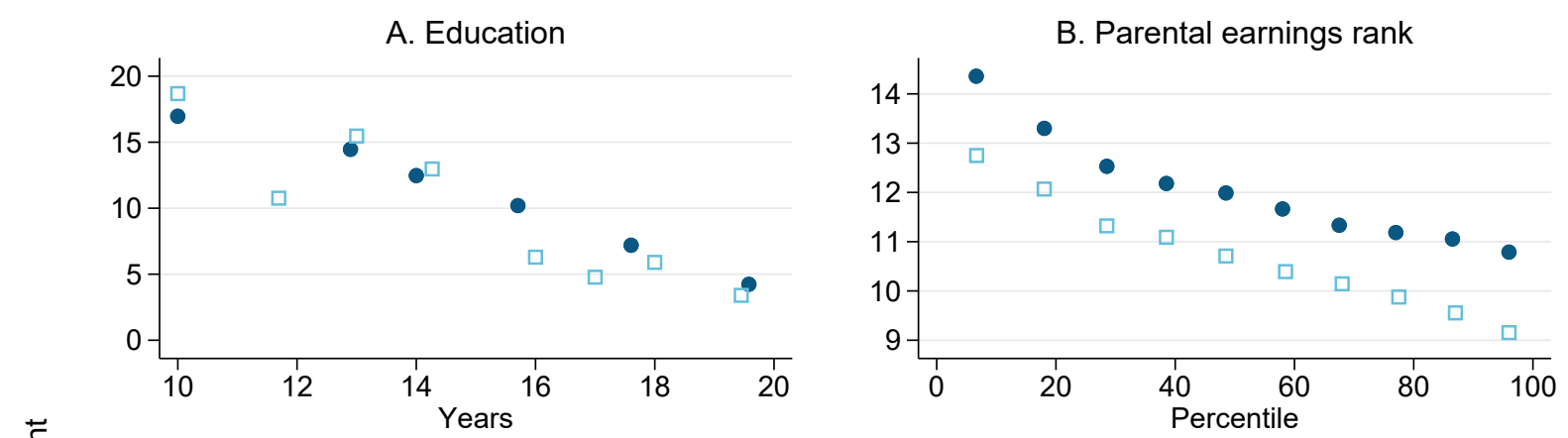

D.
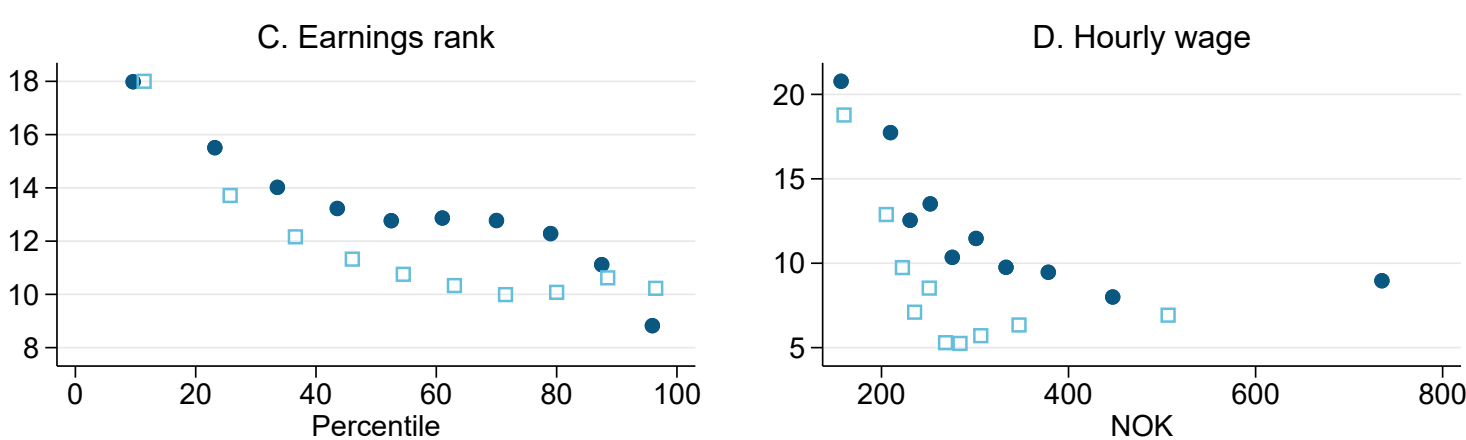

- Men

Women

Note: Panel A shows the number of school years associated with the highest completed education on the horizontal axis. In panel $\mathrm{B}$, the scale is the parent's income rank, and the location of the data points is determined by a division into 10 equal cells. Parents' income is measured at age 52-58 for all employees born before 1983, then the measurement window is shifted one year forward for each year the person is born after this. In Panel C, the income rank is based on their own "so far-in-life" professional income (up to 2017) and each birth cohort and gender are ranked separately. Both in panels B and C, the rankings were made within the entire population residing in Norway, while the division into 10 equal cells was made within the group of workers included in our analysis.

There is also a systematic pattern by age and country of birth. This is illustrated in Figure 9. There is a clear pattern that young people have been hit harder than the elderly, and that immigrants are more vulnerable than Norwegian-born. 
Figure 9: Layoffs by gender, age and country of birth

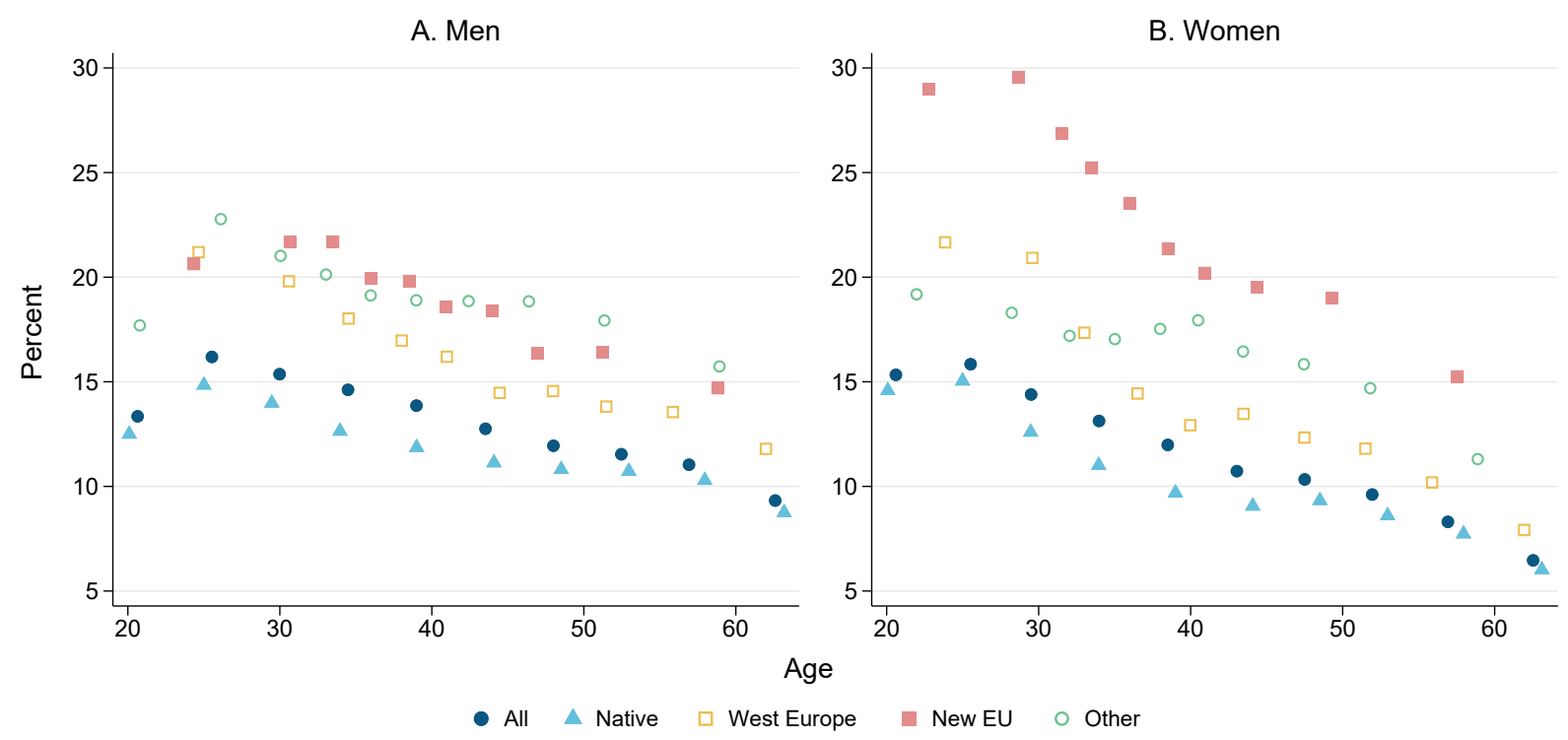

Note: Native includes children born in Norway by immigrant parents. In the group "Western Europe etc.," Sweden, Germany and Denmark are the three largest country groups in the analysis sample. "New EU countries" includes countries with membership since 2004; Poland and Lithuania are the two largest country groups in the analysis sample. In the "Other" group, the Philippines, Thailand, Eritrea, Somalia and Iraq are the five largest country groups.

Within our data period, few wage earners have lost income during the crisis, since the laid off are secured full pay for the first 20 days up to an annual income of approximately NOK 600,000 (USD 56,000). However, if the crisis persists, there is a risk of significant loss of income for the laid-off and their families. The ability of families to manage a period of reduced (or lost) income will depend on how much income they used to have and access to liquid financial reserves. Figure 10 shows clear indications that the likelihood of being laid off or dismissed is higher for less financially secure households. This pattern is most clearly seen in panel A (household income) and B (the size of bank deposits), but there is also a clear systematic pattern when we look at the household's interest burden relative to income. Those with the greatest interest burden are at the highest risk of being laid off or terminated. The U-shape is due to the fact that many people with particularly low financial resources also do not have debt, primarily because a large proportion of them do not own their own housing. 
Figure 10: Layoffs by household income and total bank deposits
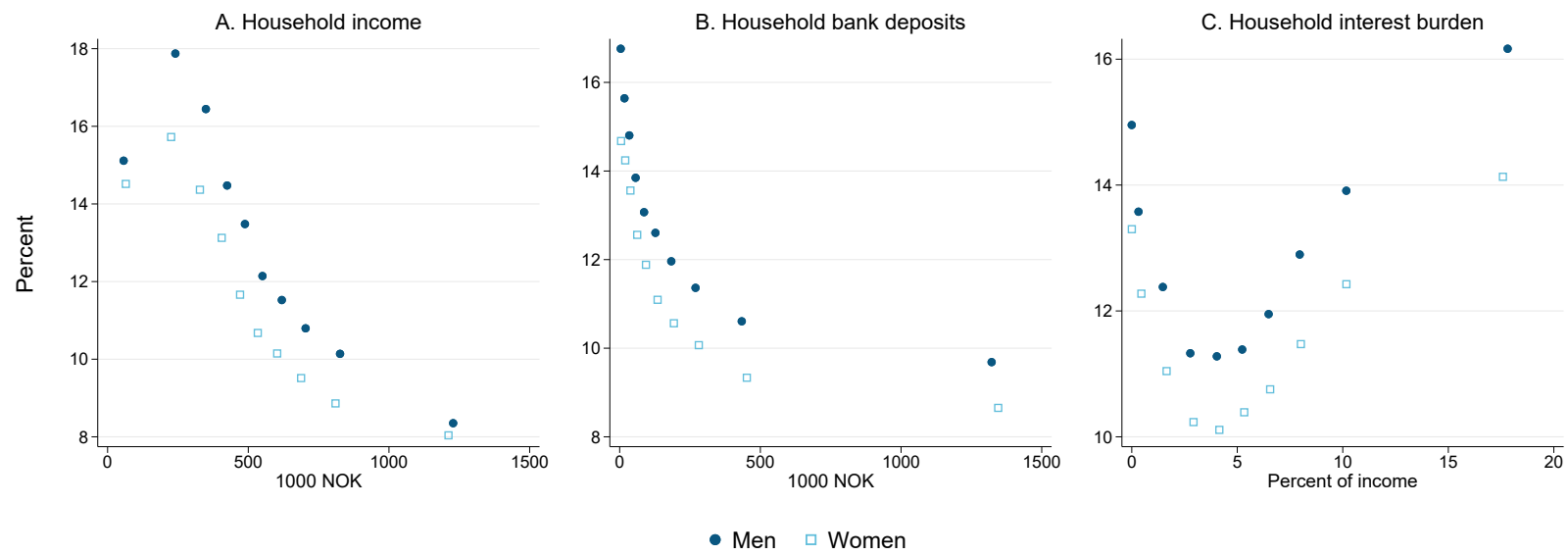

Note: Household income is adjusted for family composition (household income divided by the square root of the number of family members) .

Having children is another important dimension of socioeconomic differences between families, both because of the implications for the behavior of parents and because of the potential of adverse outcomes for children. Figure 11 illustrates that families with children experienced a little bit higher rate of layoffs at the bottom of the distribution and a bit lower at the top. Figure 11 focuses on children under 13 , because this is a group for which childcare considerations are very important. The interaction of the crisis with childcare is complex - on one hand, school closures have an obvious consequence of creating a childcare crisis as well. The crisis package in Norway adjusted the care benefit parents normally receive to look after their sick children to fit the current circumstances. The days were doubled for each parent, there was no requirement of the child being sick, and it allowed parents to transfer the days to the other parent in cases where one parent had socially critical work. This alleviated this problem somewhat. However, laid off workers by definition are not the ones that used the care benefit. At the same time, workers that can work from home have a (costly, but still) ability to take care of their own children while continuing to work. These considerations may be contributing to a different direction of the effect for lower and higher income individuals. 
Figure 11: Layoffs depending on the presence of a child under 13 at home. By position in the ageand gender-specific lifetime earnings distribution

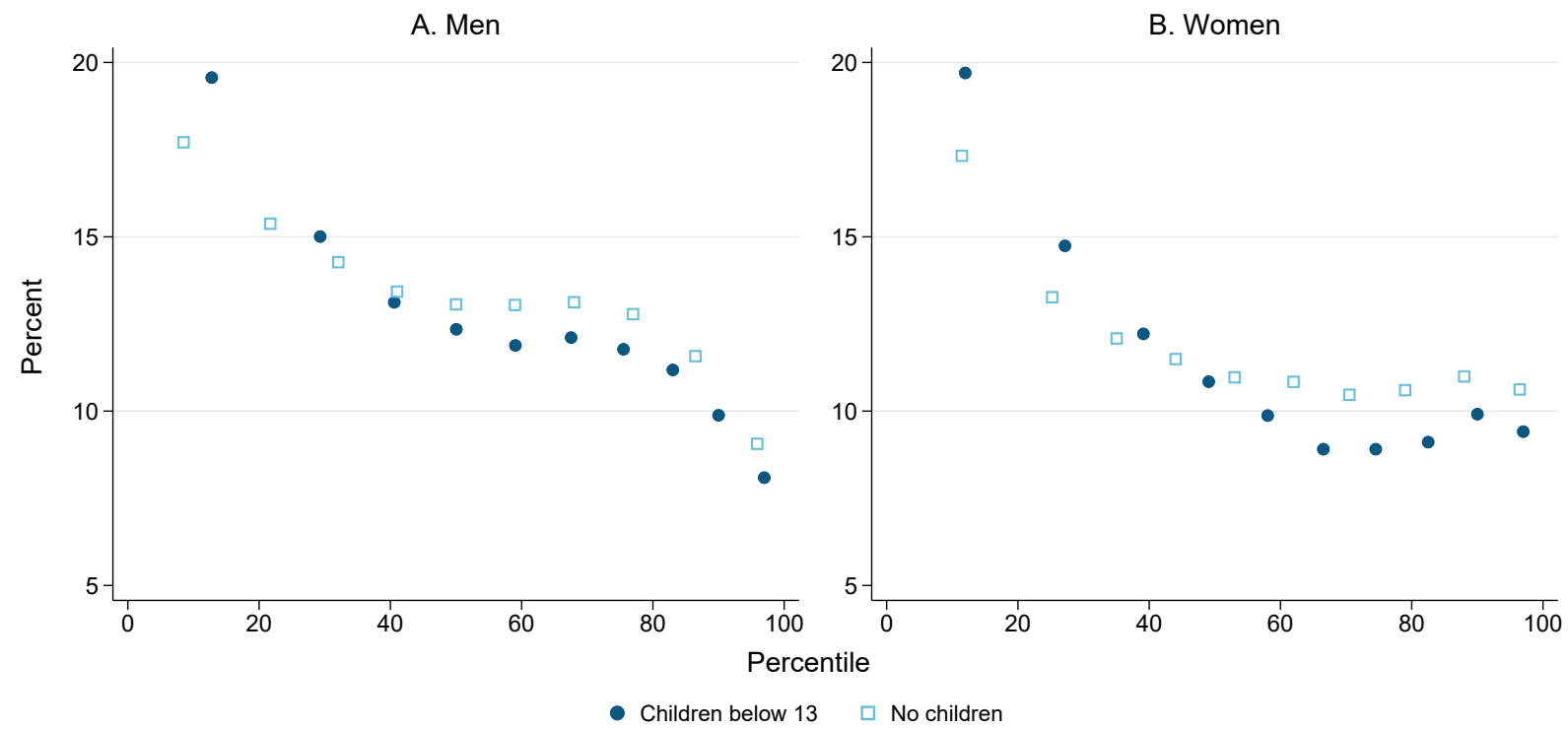

The discussion so far makes it clear that layoffs are strongly associated with a number of socioeconomic characteristics and result in a "social gradient" of the crisis. The social gradient mainly arises as a result of the underlying social gradient in the professional structure in Norway. The first phase of the coronavirus crisis affected people in occupations involving close physical contact with other people, but without essential jobs. This pattern follows, to some extent, directly from the authorities' decision to close or restrict some types of businesses that involve the risk of spreading the virus, such as hairdressing salons and restaurants. The result of this is shown in Figure 12, where we show the proportion of laid-off workers by occupation, with occupations placed on the horizontal axis according to the extent to which they involve physical proximity with other people. The size of each data point is proportional to the size of the occupational group in our data, and for some of the largest occupational groups we have applied a professional designation in the figure. Figure 12 illustrates a clear positive correlation between physical proximity in the profession and the proportion of layoffs among both women and men. 
Figure 12: Layoffs by occupation and the profession's tendency to involve physical proximity with others

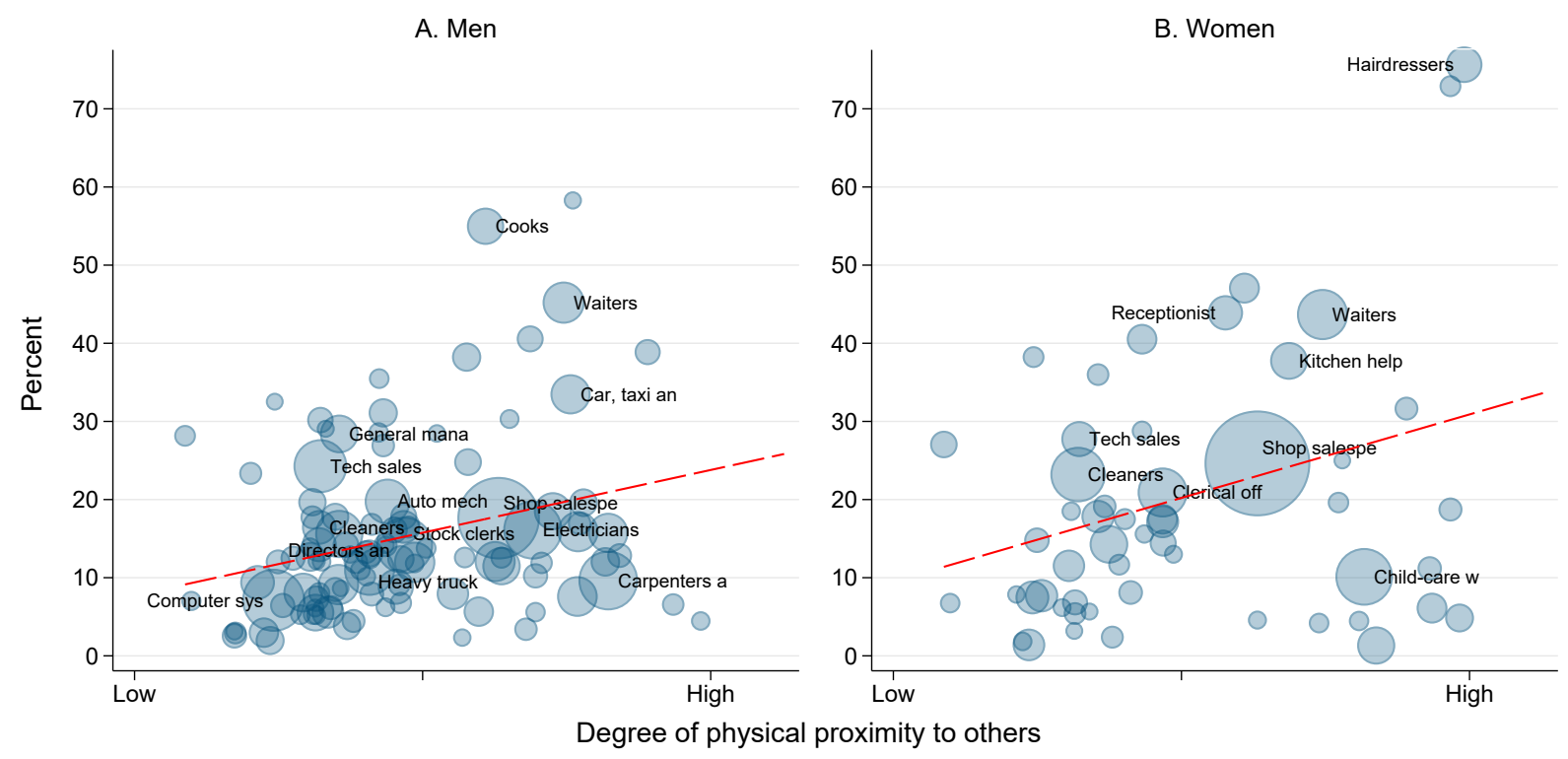

Note: Physical proximity at work is based on information provided by O*NET; see further description in section on data. The data is limited to occupations in the private sector; occupation - gender combinations with fewer than 2,500 individuals are excluded from the figure. The figures also show the regression fit of industry-gender-specific unemployment claims on physical proximity, weighted by the number of workers in the occupation. The regression coefficient is 3.73 [0.69] for men and 4.97 [0.83] for women.

Do industry and occupation specific impacts fully account for the presence of the gradient? We investigate this question by regressing the likelihood of layoffs on individual characteristics and a set of progressively more detailed fixed effects in Table 2. The sample is restricted to private sector employees only. Without accounting for any firm or occupational characteristics, the multivariate analysis confirms the relevance of education and hourly wage. It also indicates that younger workers and those with shorter tenure were more strongly affected. There is an indication here that women were more affected (this is in contrast to Figure 7 that includes both public and private sector employees), and so were parents. Adding occupational or industry fixed effects attenuates gender, education, tenure and wage effects, but they remain statistically significant. Accounting for industry or occupation characteristics flips the sign of the age effect, suggesting that within industries or occupations it may be older workers that are more strongly affected, for a given tenure. Firm and combined firm and occupation effects attenuate most of these further somewhat.

An intriguing finding is the effect of having young children that remains almost unaffected once firm and job fixed effects are controlled for. Furthermore, while the gender difference for those without children disappears, the gender interaction with children becomes stronger. Once firm and occupational differences are accounted for, the gender effect is only associated with the presence of young children: women with young children are more likely to be laid off and this is a within-firm and within-occupation effect. This potentially points to the employers accounting for childcare in making layoff decisions, either unilaterally or in cooperation with employees who may prefer 
temporary layoff in the presence of childcare obligations. It may also reflect employers' belief that the productivity of female workers would be most strongly affected by child care obligations due to school and kindergarten closures, although it remains puzzling why temporary layoffs rather than the adjusted care benefit would be used.

Table 2: Socio-economic characteristics and layoffs. Private sector.

\begin{tabular}{|c|c|c|c|c|c|}
\hline & (1) & $(2)$ & $(3)$ & $(4)$ & $(5)$ \\
\hline & \multirow[b]{2}{*}{ OLS } & \multicolumn{4}{|c|}{ Fixed Effects } \\
\hline & & Occupation & Industry & Firm & $\begin{array}{l}\text { Firm and } \\
\text { occupation }\end{array}$ \\
\hline \multirow[t]{2}{*}{ Female } & $5.246^{* * *}$ & $1.264^{* * *}$ & $0.518^{* * *}$ & $0.348^{* * *}$ & 0.158 \\
\hline & $(0.345)$ & $(0.209)$ & $(0.156)$ & $(0.125)$ & $(0.107)$ \\
\hline \multirow[t]{2}{*}{ Child under 13} & $1.012^{* * *}$ & $1.016^{* * *}$ & $1.102^{* * *}$ & $0.908^{* * *}$ & $0.844^{* * *}$ \\
\hline & $(0.134)$ & $(0.108)$ & $(0.106)$ & $(0.0901)$ & $(0.0874)$ \\
\hline \multirow{2}{*}{$\begin{array}{l}\text { Female and } \\
\text { child under } 13\end{array}$} & 0.103 & $0.800^{* * *}$ & $1.346^{* * *}$ & $1.256^{* * *}$ & $1.242^{* * *}$ \\
\hline & $(0.232)$ & $(0.178)$ & $(0.163)$ & $(0.159)$ & $(0.154)$ \\
\hline \multirow[t]{2}{*}{ Age } & $-0.0265^{* *}$ & $0.0317^{* * *}$ & $0.0644^{* * *}$ & $0.0495^{* * *}$ & $0.0490 * * *$ \\
\hline & $(0.0108)$ & $(0.00755)$ & $(0.00660)$ & $(0.00590)$ & $(0.00608)$ \\
\hline \multirow{2}{*}{$\begin{array}{l}\text { Education } \\
\text { (years) }\end{array}$} & $-1.106^{* * *}$ & $-0.343^{* * *}$ & $-0.357^{* * *}$ & $-0.122^{* * *}$ & $-0.0882^{* * *}$ \\
\hline & $(0.0559)$ & $(0.0255)$ & $(0.0249)$ & $(0.0180)$ & $(0.0174)$ \\
\hline \multirow[t]{2}{*}{ Tenure } & $-0.185^{* * *}$ & $-0.143^{* * *}$ & $-0.124^{* * *}$ & $-0.103^{* * *}$ & $-0.0967 * * *$ \\
\hline & $(0.0246)$ & $(0.0160)$ & $(0.0130)$ & $(0.00994)$ & $(0.00966)$ \\
\hline \multirow{2}{*}{$\begin{array}{l}\text { Log hourly } \\
\text { wage }\end{array}$} & $-4.649 * * *$ & $-3.114^{* * *}$ & $-2.366^{* * *}$ & $-1.147^{* * *}$ & $-1.038^{* * *}$ \\
\hline & $(0.275)$ & $(0.182)$ & $(0.165)$ & $(0.122)$ & $(0.119)$ \\
\hline $\mathrm{N}$ & 1723833 & 1723833 & 1723833 & 1723833 & 1723833 \\
\hline \multicolumn{2}{|l|}{ \# Fixed effects } & 349 & 571 & 149963 & $149963+349$ \\
\hline $\mathrm{R}^{2}$ & 0.020 & 0.129 & 0.184 & 0.434 & 0.439 \\
\hline
\end{tabular}

Figure 13 illustrates that this gender and parental effect is not an artifact of the choice of controls. It shows the deviation of the likelihood of layoffs from firm-specific means (residuals from regression of the layoff indicator on firm fixed effects) for men and women, separately for those with and without children under 13. The effect of having a child under 13 is stronger for women than for men and in each case it is driven by workers at the bottom of the distribution. 
Figure 13: Within-firm relationship between having children under 13 and layoffs. By position in the age- and gender-specific lifetime earnings distribution

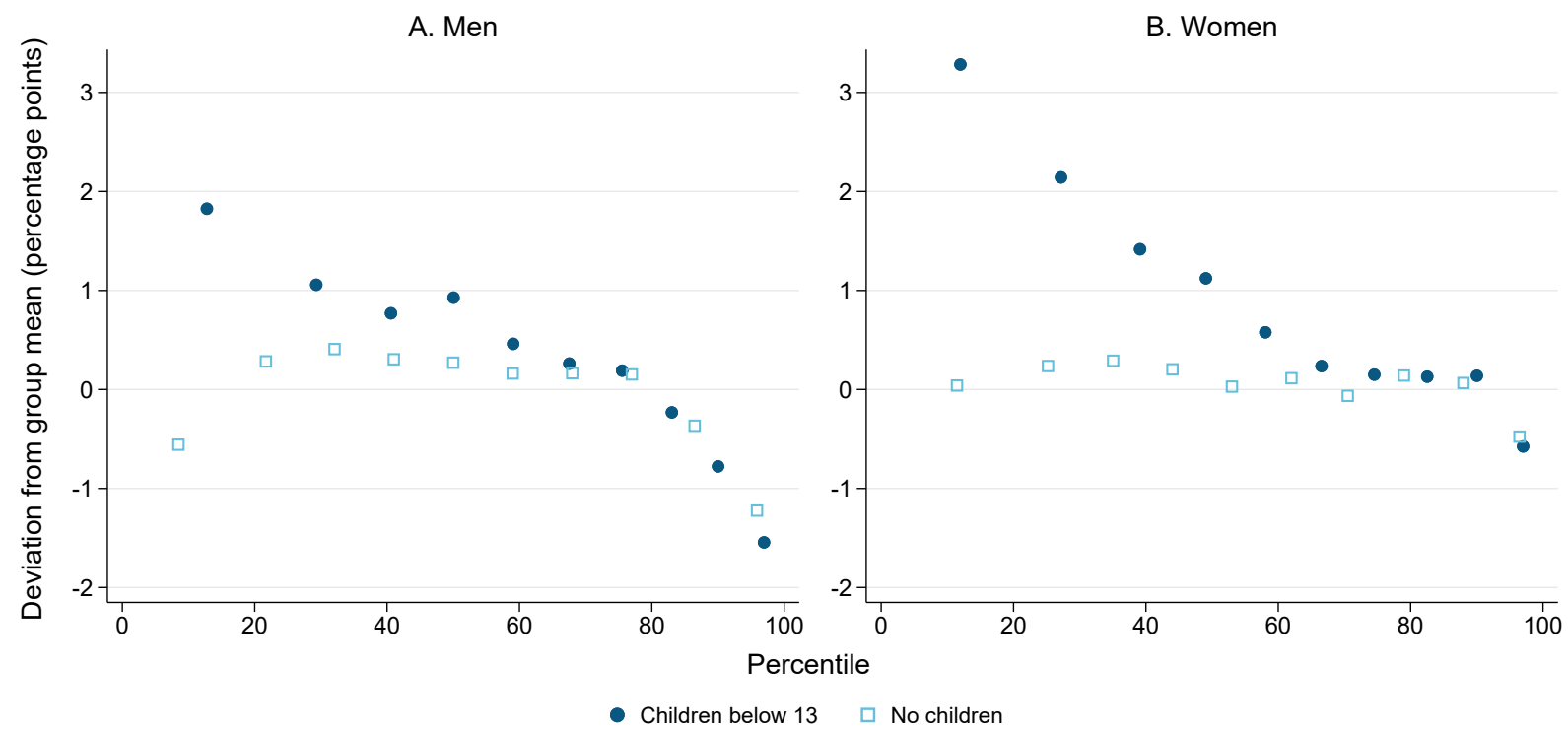

Note: The Figure shows the average residuals from regression of layoff indicator on firm fixed effects and should be interpreted as a deviation from firm-specific layoff rate.

\section{The driving forces behind lay off decisions}

The relevance of physical proximity for layoff decisions is natural, but it masks the dynamics that these considerations played. As Figure 14 demonstrates, this association applies to the immediate effect of the lockdown measures. The top panels show the relationship during the first 9 days after lockdown measures were introduced, the bottom ones show it in the weeks that followed. The association is much stronger in the initial weeks. A one standard deviation increase in physical proximity requirements of an occupation is associated with a very significant 2.75 percentage point increase in layoffs for men (t-stat of over 5 ) and 4.82 percentage point increase for women (t-stat of over 6). The effect weakens afterwards to 0.92 for men (still significant with t-stat of 4 ) and a small and insignificant one for women. While physical proximity plays a large role in the initial impact, it becomes less of a factor over time, suggesting the presence of spillovers to other parts of the economy. 
Figure 14: Layoffs by occupation and the profession's tendency to involve physical proximity with others, over time

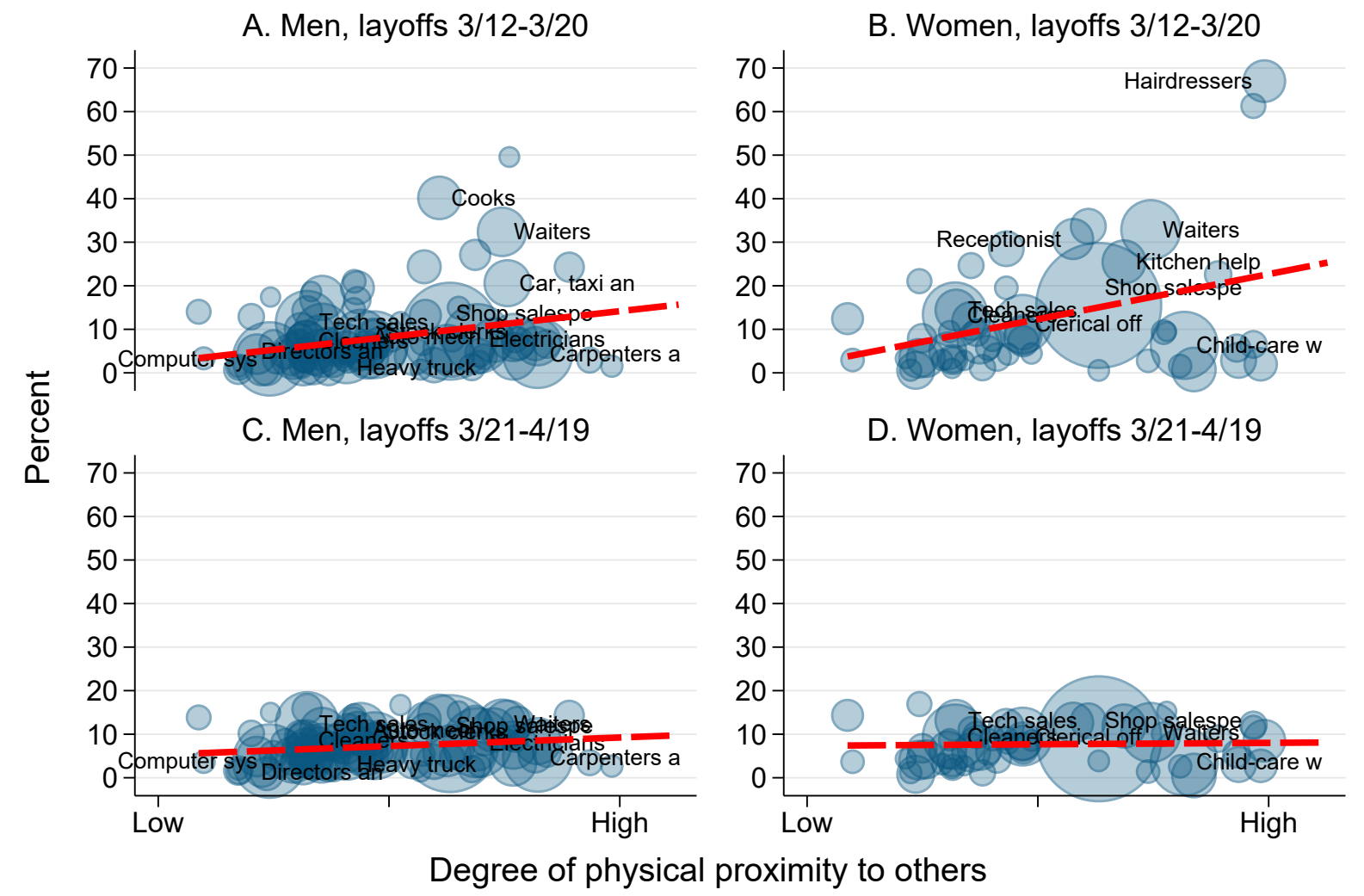

Note: See Figure 12. The regression coefficients are 2.75 [0.50] and $0.92[0.23]$ for men and $4.82[0.67]$ and 0.15 [0.23] for women.

As the economic crisis spreads both internationally and through the economy through falling demand for goods and services from the first affected businesses, we expect jobs with low physical proximity and contagion risk to be affected as well. This is also what we find in the data. In Figure 15 we visualize how the composition of the new unemployment insurance applicants has changed day by day after the layoff wave took off in earnest on Friday 13 March. While physical proximity was a driving factor in the early days, the importance of this was greatly diminished in just a few days. As the crisis spread through the economy, we also see that the average age is increasing and the proportion of women is falling. In particular, while in the first few days of the crisis layoffs were skewed toward females, this initial effect reversed quickly and by the end of the period more men than women were laid off altogether.

When it comes to indicators of the social gradient, the picture is more mixed, and the variations from day to day are rather moderate (note the scales on the vertical axes). We still see signs that the average hourly wage among the laid-off increased somewhat during the first week. For all socio-economic indicators, the affected individuals fall below the mean of the characteristic in the analysis sample. 
Figure 15: Characteristics of laid-off workers - day by day 3/3-4/19
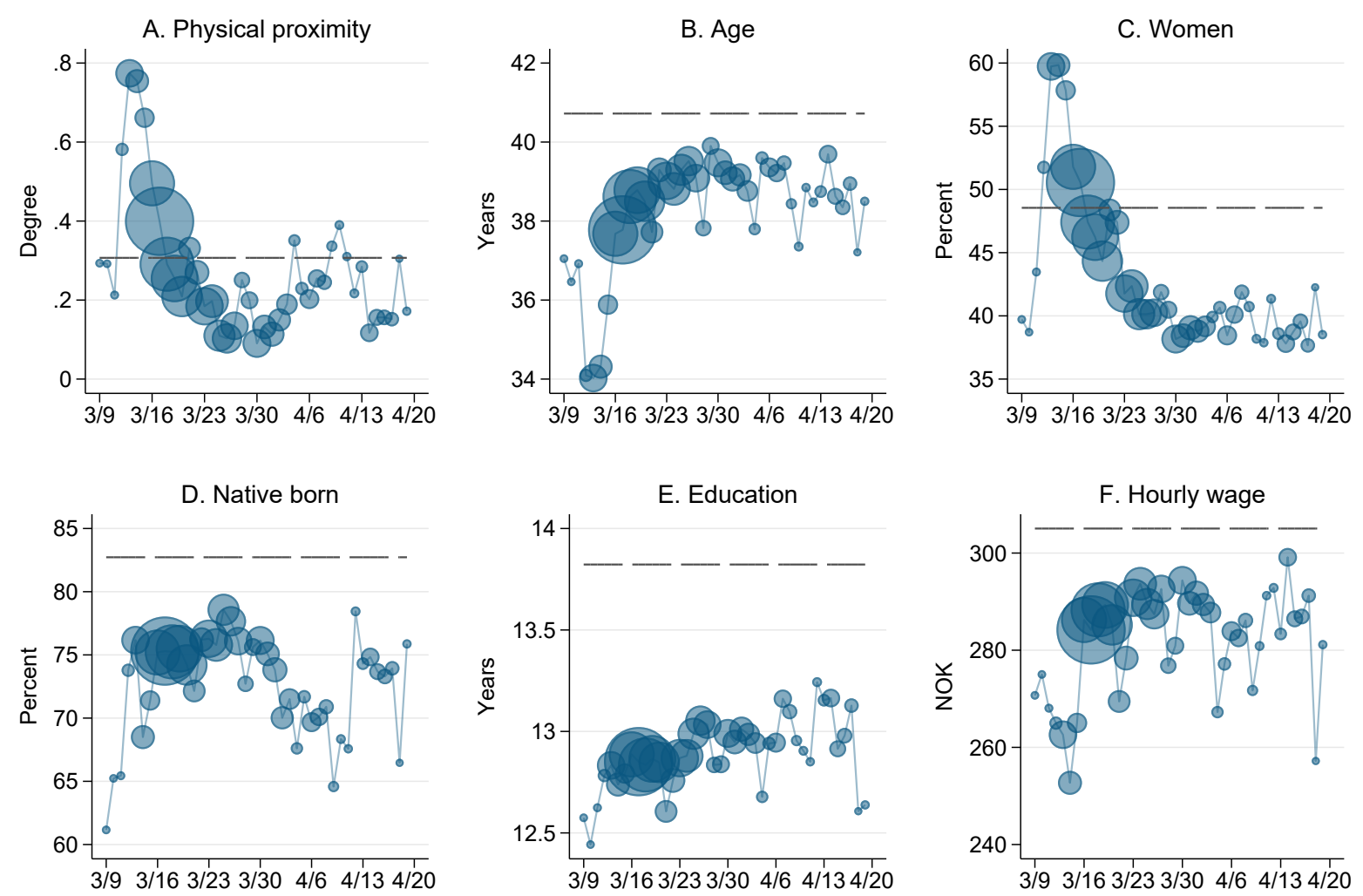

Note: The size of the circles is proportional to the number of layoffs on each day. The definitions of "physical proximity at work" are described in more detail in the section on databases. See also note to Figure 8 . The figures also show the mean value of each characteristic as a dashed line.

Which firms responded most strongly? Figure 16 shows the relationship between layoffs and a set of firm characteristics: productivity, equity and employment. In each case there is a very strong negative relationship between these proxies for the strength of a firm and layoffs. 
Figure 16: Characteristics of firms and layoffs
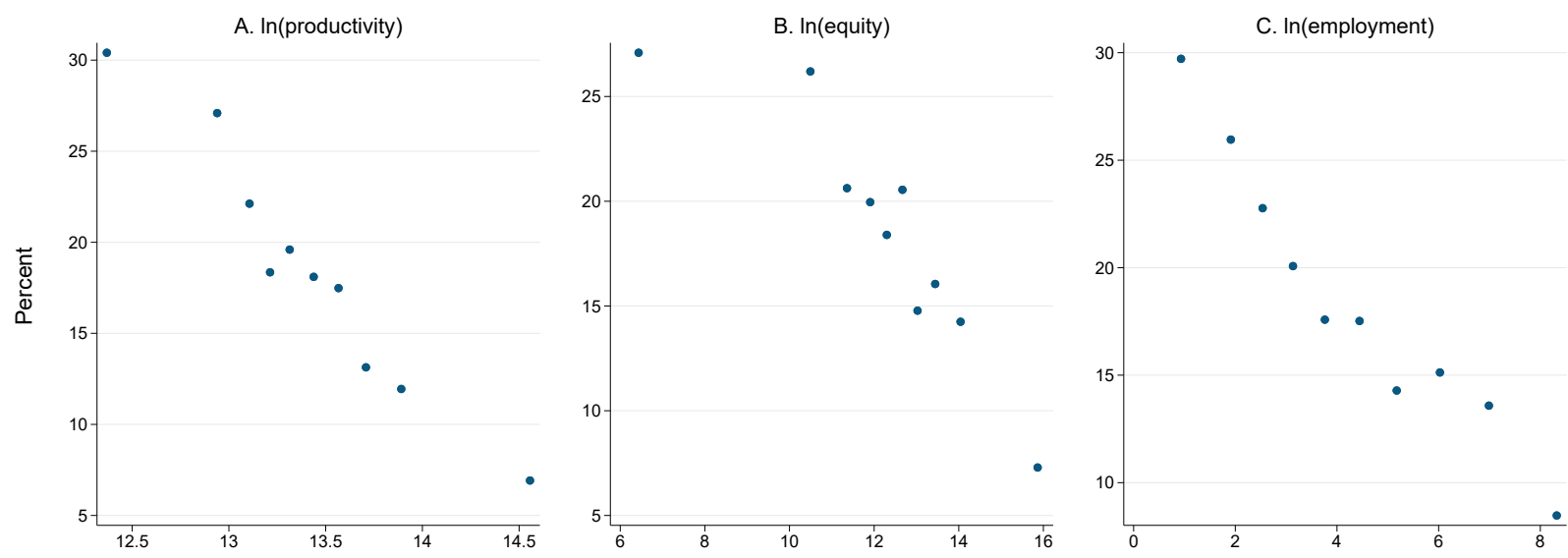

Note: Each point corresponds to a decile of the distribution. Productivity is measured by value added. Employment represents the number of full-time equivalent workers.

Table 3 shows that this association is strong and statistically significant and it persists even within industries.

Table 3: Characteristics of firms and layoffs

\begin{tabular}{lllll}
\hline & $(1)$ & $(2)$ & $(3)$ & $(4)$ \\
& OLS & Industry FE & OLS & Industry FE \\
\hline Log productivity & $-10.13^{* * *}$ & $-3.86^{* * *}$ & $-6.90^{* * *}$ & $-3.00^{* * *}$ \\
& $(0.54)$ & $(0.39)$ & $(0.61)$ & $(0.38)$ \\
Log equity & & & $-1.17^{* * *}$ & $-0.74^{* * *}$ \\
per worker & & & $(0.20)$ & $(0.17)$ \\
Log employment & & & $-2.13^{* * *}$ & $-1.52^{* * *}$ \\
(No. FTE) & & & $(0.21)$ & $(0.14)$ \\
\hline N & $1,415,131$ & $1,415,131$ & $1,343,602$ & $1,343,602$ \\
R-sq & 0.023 & 0.169 & 0.040 & 0.176 \\
\#Industry FE & & 536 & & 532 \\
\hline
\end{tabular}

Note: The sample is restricted to private sector workers working for firms that can be linked to the 2017 accounting data. Dependent variable is an indicator set to 100 for workers laid off between March $1^{\text {st }}$ and April $19^{\text {th }}$. Productivity is calculated as operating profit plus labor costs divided by the number of man-years, where man-years are calculated on the basis of a-forms filed in 2019 and accounting figures are based on the annual accounts for 2017. Employment is measured as the number of manyears (FTE) and calculated fromf a-forms filed in 2019. Standard errors are clustered within firms and reported in parentheses. Significance level of $1 \%$ is denoted by ${ }^{* * *}, 5 \%$ by $* *$ and $10 \%$ by *.

Figure 17 shows a timeline focusing on the characteristics of the companies that are laying off employees. In Panel A we see that the problems affect companies with higher and higher labor productivity (measured by total wages and profits per full-time equivalent), in Panel B that they affect larger and larger companies, and in Panels $\mathrm{C}$ and $\mathrm{D}$ that fewer and fewer of the laid-off 
workers come from companies with low equity and high debt.

Figure 17: Characteristics of private-sector enterprises laying off workers - day by day in the period $3 / 3-4 / 19$
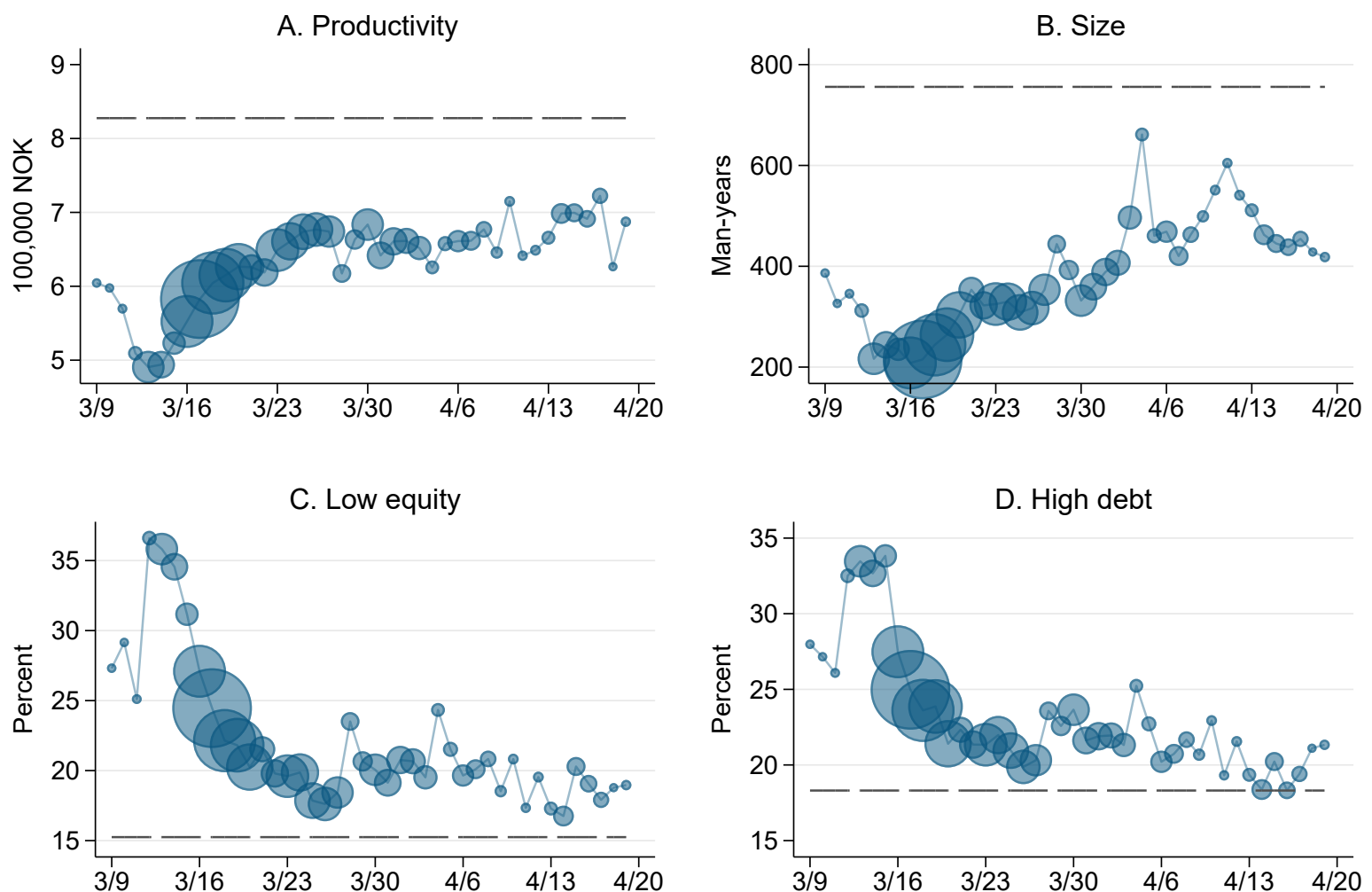

Note: The size of the circles is proportional to the number of layoffs on each day. In Panel A, productivity is calculated as operating profit plus labor costs divided by the number of man-years, where man-years are calculated on the basis of a-forms in 2019 and accounting figures are based on the annual accounts for 2017. In panel B, the number of man-years is calculated from a-forms filed in 2019. In Panel C, low equity is defined as equity below NOK 40,000 per full-time equivalent. In Panel D, high debt is high debt defined as debt that exceeds eight times equity. The figures also show the mean value of each characteristic as a dashed line.

Figure 18 shows the extent of layoffs in selected industries, affected by the crisis in very different ways. Hotels and restaurants were among the first industries directly affected, and during the first days they accounted for 30-35\% of the new unemployment benefit applications. In just over a week, this percentage dropped to about $10 \%$. Soon after, layoffs in the retail sector followed. They were accompanied by layoffs among wholesalers that then continued in the following weeks. Layoffs in construction were not as important initially, but then continued at a level about proportional to the industry share. It appears that the petroleum industry has been more indirectly affected by a dramatic fall in oil prices than the domestic response to the crisis, as indicated by the absence of extensive layoffs during the first weeks of the crisis. The sector accounted for only $0.7 \%$ of new unemployment claims during the initial nine days of the crisis, and $1.8 \%$ of all layoffs between March 21 and April 19. 
Figure 18: Layoffs in different industries over time
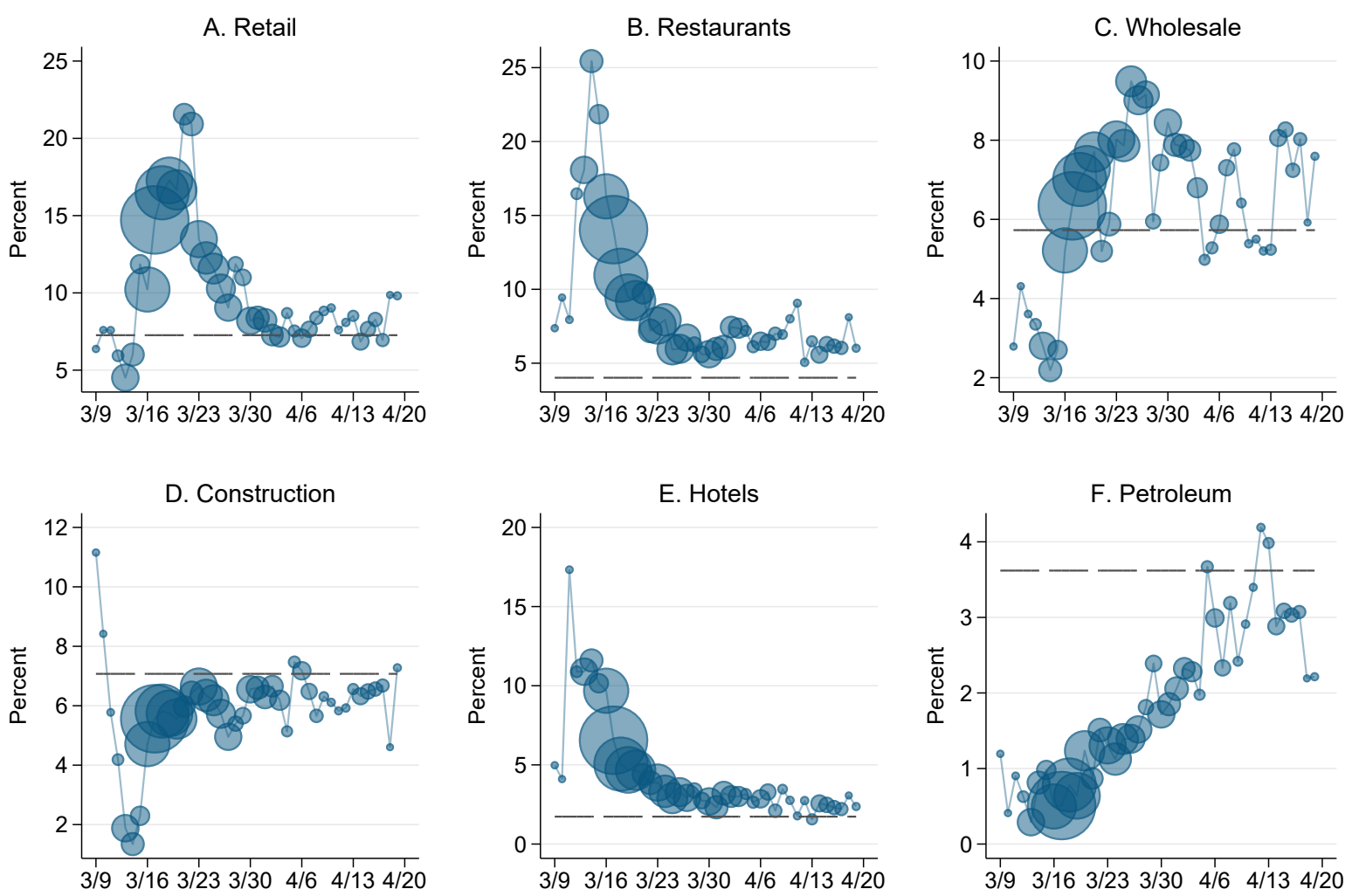

Note: The petroleum industry with 3.6 percent of total private-sector employment comprises extraction of crude oil and natural gas, drilling and other services related to extraction, construction of platforms and modules, furnishing and installation work and supply bases. The horizontal line represents the share of employment accounted for by a given industry

\section{Summary and conclusion}

The coronavirus crisis struck broadly, but not randomly. There are clear systematic patterns in which workers are most affected. The public sector is so far shielded from layoffs, but there are many public employees in socially critical and risk-exposed professions, especially in the health and care sectors. Here, women are far more exposed than men, and people with low incomes are more exposed than those with high incomes.

Among all employees, we find that the risk of layoffs or dismissals during the first phase of the crisis is higher the lower the education, income, hourly wage and social class background of an employee. While initially, women bear the brunt of the layoffs due to their over-representation in sectors explicitly targeted by social distancing policy measures, over time this effect was more than offset as the rest of the economy responded. Males are more exposed to layoffs than women, because more men work in the private sector. Within the private sector, the gender effect is associated with the presence of young children: women with young children are more likely to be laid off comparing workers within the same firm and occupation by means of fixed effects. This 
points to the importance of childcare in understanding the labor market impact of the crisis (see also Dingel, Patterson and Vavra, 2020).

As the crisis spreads, both internationally and across sectors domestically, we see signs that unemployment seekers are coming from ever-increasing occupations in the private sector. The companies that are laying off have also changed over time. While industries such as tourism and businesses with low productivity and equity dominated the first few days, we see a trend towards more "average" businesses being affected.

The Norwegian context is also useful in judging the extent to which the crisis is expected to be permanent. In the short term, about 1/10th of layoffs are classified as "permanent" and correspond to severing employment relationships. The remaining layoffs are temporary. While the incentives to lay off workers permanently are not strong even for firms in distress, as temporary layoffs may be converted to permanent later on and permanent layoffs may trigger severance obligations, this decomposition gives at least some reasons for hope that the great majority of layoffs in countries where this choice is not easily available (such as the US) may in fact be reversible.

\section{References}

Adams-Prassl, A., Boneva, T., Golin, M., and Rauh, C. (2020) Inequality in the Impact of the Coronavirus Shock: Evidence from Real Time Surveys, IZA Discussion Paper 13183.

Bartik, A., Bertrand, M., Lin, F., Rothstein, J., and Unrath, M. (2020) Labor Market Impacts of COVID-19 on Hourly Workers in Small- and Medium-Sized Businesses: Four Facts from Homebase Data., Online at https://irle.berkeley.edu/labor-market-impacts-of-covid-19-onhourly-workers-in-small-and-medium-sized-businesses-four-facts-from-homebase-data2/, accessed on 4/30/2020.

Berg, H., Larsen, K. A., Klingenberg, S., og Solheim, Ø. B. (2015) Permitteringer og avgang fra arbeidslivet. Rapport 2015-007 Proba samfunnsanalyse.

Bratsberg, B., Raaum, O., and Røed, K. (2010) When Minority Labor Migrants Meet the Welfare State. Journal of Labor Economics, Vol. 28, No. 3, 633-676.

Bratsberg, B., Raaum, O., and Røed, K. (2018) Job Loss and Immigrant Labor Market Performance. Economica, Vol. 85, 124-151.

Coibion, O., Gorodnichenko, Y., and Weber, M. (2020) Labor Markets During the COVID-19 Crisis: A Preliminary View, NBER Working Paper No. 27017.

Direktoratet for samfunnssikkerhet og beredskap (2016) Samfunnets kritiske funksjoner. HR 2350.

Dingel, J., Patterson, C., and Vavra, J. (2020) Childcare Obligations Will Constrain Many Workers When Reopening the US Economy. Becker Friedman Institute for Economics at University of Chicago, Working Paper 2020-46. 
Dustmann, C., Glitz, A., and Vogel, T. (2010) Employment, Wages, and the Economic Cycle: Differences between Immigrants and Natives. European Economic Review, Vol 54, No. 1, 1-17.

Hoen, M. (2016) Occupational crosswalk, data and language requirements. Working Paper 1/2016. The Ragnar Frisch Centre for Economic Research.

Hoynes, H. Miller, D. L., and Schaller, J. (2012) Who Suffers During Recessions? Journal of Economic Perspectives, Vol. 26, No. 3, 27-48.

NAV (2020) Statistics on unemployment insurance applications. Updated daily at 10am on http: //www.nav.no.

Yagan, D. (2019) Employment Hysteresis from the Great Recession. Journal of Political Economy, Vol. 127, No. 5, 2505-2558. 